\title{
Comprehensive Evaluation of Comprehensive Benefits of Joint-Stock Commercial Banks
}

\author{
Rongping $\mathrm{Li}$ \\ School of Economics and Management \\ Hebei University of Science and Technology \\ Shijiazhuang, China \\ 1256108972@qq.com
}

\begin{abstract}
First, this thesis describes the grey relational analysis method and the evaluation model. And then it determines the evaluation index system based on the average financial indicators data of the six joint-stock commercial banks in 2011-2015. Finally it makes an empirical analysis on the comprehensive benefit of six joint-s tock commercial banks by grey correlation analysis, and concludes with the ranking of the comprehensive benefit correlation degree of six joint-stock commercial banks. The thesis further analyzes the advantages and disadvantages of the six banks in various aspects from the aspects of commercial banks. And it puts forward some corresponding countermeasures to the six commercial banks to improve their competitiveness for the future developments. It is of great practical significance to improve the overall strength of China's joint-stock commercial banks and promote the healthy development for China's financial industry.
\end{abstract}

Keywords-joint-stock system Commercial Banks; Comprehensive benefits; Grey relational analysis; Comprehensive evaluation

\section{INTRODUCTION}

Since the reform and opening up, China's banking system has gradually taken shape, which has made significant contributions to the development of China's financial industry and has played an important role in the stability of the society. At present, China's banking system is intensifying efforts to reform. In addition to institutional reforms, it is more important to expand the scope of services, enhance business contacts, and improve performance and quality. In a comprehensive view, efficiency is the key. As a new force in the Chinese securities market, the companies in the banking system are attracting more and more attention from the scale of assets, the ability to influence markets, the potential and the growth trends. More attention, ranking the bank's overall benefits will provide investors with a lot of convenience. Therefore, it is of urgent practical significance to evaluate the benefits of joint-stock commercial banks in the banking system.[1] [7]

The research and development of science and technology in shijiazhuang in 2018: analysis and development of science and technology SMEs in shijiazhuang (185790387A)

The innovation ability and development of shijiazhuang high-tech enterprise under the background of collaborative innovation of beijing-tianjinhebei region. (185790065A)

\author{
Aoyun Feng* \\ School of Economics and Management \\ Hebei University of Science and Technology \\ Shijiazhuang, China \\ 931576827@qq.com
}

\section{GREY CORRELATION ANALYSIS METHOD AND EVALUATION MODEL}

\section{A. Grey correlation analysis method.}

In the process of system development, if the trend of two factors is consistent, the degree of synchronous change is higher, the correlation degree is higher. On the contrary, it is lower. Therefore, the grey correlation analysis method is based on the similar or different degree of development trend among factors, and the "grey correlation degree" is a method to measure the degree of correlation between factors.

\section{B. Evaluation model}

- Determine the reference sequence that reflects the behavior characteristics of the system and the comparison sequences that affect system behavior.

- Non-dimensionalization of reference and comparison sequences

- Refer to the gray correlation coefficient of the reference sequence and the comparison sequence.

- Strives for the correlation

- Sort the correlation.

III. THE DETERMINATION OF COMPREHENSIVE BENEFIT EVALUATION INDEX SYSTEM OF JOINT-STOCK COMMERCIAL BANKS.

It is directly related to the quality of evaluation that the setting index system is scientific and reasonable. Therefore, it is necessary to establish a set of scientific, reasonable and practical evaluation indicators to make a true and objective assessment of the comprehensive benefits of these six jointstock commercial banks.

In view of the above standards, this article makes conclusion in accordance with the principle of systematic, scientific, operability and comparability. In this paper,we establish 11 financial indicators from profitability, solvency, capital ability, and development trend and security aspects combined with the six joint-stock commercial Banks of the actual situation of the financial statements. And the 11 financial indicators include return of equity, return on net worth, asset-liability ratio, liquidity ratio, loan-to-deposit ratios, capital adequacy ratio, turnover of current asset, growth rate of 
total assets, main business growth rate, and profit growth after tax, non-performing loans ratio. At the same time, we first carry out the dimensionless treatment in order to eliminate the index dimension, and then use the analytic hierarchy process(AHP) to weight the data.

In order to facilitate understanding and calculation, we apply the analytic hierarchy process(AHP) to the valuation of each indicator. In the first-level index level, the B1, B2, B3, B4, B5 represent profitability, solvency, capital ability, development trend and security. The level $\mathrm{C}$ represents the secondary indicators and the weight of each indicator in the level B. In profitability(B1), the return of equity is $\mathrm{C} 1$, the return on net worth is $\mathrm{C} 2$. In solvency(B2), the asset-liability ratio is $\mathrm{C} 1$, liquidity ratio is $\mathrm{C} 2$, loan-to-deposit ratio is $\mathrm{C} 3$. In Capital ability(B3), capital adequacy ratio is $\mathrm{C} 1$, turnover of current assets rate is $\mathrm{C} 2$. In development trend(B4), the growth rate of total assets is $\mathrm{C} 1$, the main business growth rate is $\mathrm{C} 2$, the profit growth after tax is C3. In security(B5), the nonperforming loan rate is $\mathrm{C} 1$. The next is the evaluation index system (table I ) and the specific data of the indicators (table II ).[2]
TABLE I. BANK EVALUATION INDEX SYSTEM.

\begin{tabular}{|l|l|}
\hline \multicolumn{1}{|c|}{ First-level indicators } & \multicolumn{1}{c|}{ Secondary indicators } \\
\hline \multirow{2}{*}{ Profitability(0. 510) } & Return of equity(0. 75) \\
\cline { 2 - 2 } & Return on net worth(0. 25) \\
\hline \multirow{3}{*}{ Solvency(0. 264) } & Asset-liability ratio(0. 637) \\
\cline { 2 - 2 } & Liquidity ratios(0. 258) \\
\cline { 2 - 2 } & Loan-to-deposit ratios(0. 105) \\
\hline \multirow{2}{*}{ Capital ability(0. 129) } & Capital adequacy ratio(0. 75) \\
\cline { 2 - 2 } & Turnover of current assets(0. 25) \\
\hline \multirow{3}{*}{ Development trend(0.064) } & Growth rate of total assets(0.637) \\
\cline { 2 - 2 } & Main business growth rate(0. 258) \\
\cline { 2 - 2 } & Profit growth after tax(0. 105) \\
\hline Security(0.033) & Non-performing loan ratio(1) \\
\hline
\end{tabular}

TABLE II. WEIGHT ASSIGNMENT TABLE

\begin{tabular}{|c|c|c|c|c|c|c|}
\hline & B1 & $\overline{B 2}$ & B3 & $\overline{B 4}$ & $\overline{\text { B5 }}$ & \multirow{2}{*}{$\begin{array}{c}\text { RANK } \\
\sum \mathbf{B}_{J} \mathbf{C}_{\mathrm{IJ}}\end{array}$} \\
\hline C & 0.510 & 0.264 & 0.129 & 0.064 & 0.033 & \\
\hline C1 & 0.750 & 0.637 & 0.750 & 0.637 & 1 & 0.721 \\
\hline C2 & 0.250 & 0.258 & 0.250 & 0.258 & 0 & 0.244 \\
\hline C3 & 0 & 0.105 & 0 & 0.105 & 0 & 0.034 \\
\hline
\end{tabular}

\section{Using The TeMPlate}

TABLE III. BANK EVALUATION INDEX SYSTEM

\begin{tabular}{|c|c|c|c|c|c|c|}
\hline Bank & $\begin{array}{c}\text { China Merchants } \\
\text { Bank }\end{array}$ & $\begin{array}{l}\text { Industrial } \\
\text { Bank }\end{array}$ & $\begin{array}{c}\text { Huaxia } \\
\text { Bank }\end{array}$ & $\begin{array}{c}\text { Shanghai Pudong Development } \\
\text { Bank }\end{array}$ & $\begin{array}{c}\text { China Minsheng } \\
\text { Bank }\end{array}$ & $\begin{array}{c}\text { China CITIC } \\
\text { Bank }\end{array}$ \\
\hline Return of equity & 17. 67 & 18. 90 & 17. 18 & 18. 82 & 16. 98 & 14. 55 \\
\hline Return on net worth & 17. 09 & 18. 89 & 17. 02 & 18. 52 & 16. 73 & 14. 05 \\
\hline Asset-liability ratio & 93. 39 & 94. 01 & 94. 14 & 93. 68 & 93. 15 & 93. 76 \\
\hline Liquidity ratios & 65.67 & 56.8 & 39.14 & 34. 06 & 44. 72 & 44.97 \\
\hline Loan-to-deposit ratios & 73.93 & 67.62 & 79. 10 & 76. 01 & 71.00 & 75.63 \\
\hline Capital adequacy ratio & 12. 79 & 11. 04 & 10.85 & 10. 19 & 11. 49 & 11. 87 \\
\hline $\begin{array}{l}\text { Turnover of current } \\
\text { assets }\end{array}$ & 40. 00 & 18. 00 & 11. 00 & 26. 00 & 12. 00 & 17. 00 \\
\hline $\begin{array}{l}\text { Growth rate of total } \\
\text { assets }\end{array}$ & 15. 07 & 20. 25 & 12. 53 & 20. 23 & 12. 60 & 23. 76 \\
\hline $\begin{array}{l}\text { Main business growth } \\
\text { rate }\end{array}$ & 21. 47 & 23. 58 & 7. 21 & 18. 97 & 13. 99 & 16. 37 \\
\hline Profit growth after tax & 3.51 & 6.56 & 5. 01 & 7.68 & 3. 19 & 0.69 \\
\hline $\begin{array}{l}\text { Non-performing loan } \\
\text { ratio }\end{array}$ & 1. 68 & 1. 46 & 1. 52 & 1. 56 & 1. 60 & 1. 43 \\
\hline
\end{tabular}

TABLE IV. THE RANKING

\begin{tabular}{|l|l|l|}
\hline \multicolumn{1}{|c|}{ Bank } & \multicolumn{1}{c|}{ Rank } & \multicolumn{1}{c|}{ Correlation } \\
\hline Industrial Bank & 1 & 0.944 \\
\hline $\begin{array}{l}\text { China Merchants } \\
\text { Bank }\end{array}$ & 2 & 0.927 \\
\hline $\begin{array}{l}\text { Shanghai Pudong } \\
\text { Development Bank }\end{array}$ & 3 & 0.915 \\
\hline Huaxia Bank & 4 & 0.869 \\
\hline $\begin{array}{l}\text { China Minsheng } \\
\text { Bank }\end{array}$ & 5 & 0.852 \\
\hline China CITIC Bank & 6 & 0.827 \\
\hline
\end{tabular}

Firstly, the paper selects the data from six joint-stock commercial banks' financial statements in 2011-2015(table III). And the paper's study object is the China Merchants Bank, Industrial Bank, Huaxia Bank, Shanghai Pudong Development
Bank, China Minsheng Bank and China CITIC Bank. And then the paper uses the software of social and economic statistical large statistical software package SPSS20. 0 to measure data. In the end, we conclude that the comprehensive benefit 
evaluation results of the six joint-stock commercial banks in 2011-2015(table IV), and the Industrial Bank ranking top among them.

According to table III and table IV, the six joint-stock commercial Banks have the following characteristics.

\section{A. Overall, the sixjoint-stock commercial Banks have different comprehensive benefits.}

According to table IV shows, Industrial Bank's correlation degree is 0.944 , ranks first in the six banks. It shows that the Industrial Bank's overall benefit is optimal. And the Industrial Bank also needs to maintain the strength, and then make greater progress.

The correlation of China CITIC Bank is only the lowest 0 . 827. It suggests that China CITIC Bank has the worst overall performance of the six banks. So the China CITIC Bank urgently needs to strengthen the attention on improving the comprehensive benefit of the bank.

In second place is China Merchants Bank, and then Shanghai Pudong Development Bank third, Huaxia Bank fourth, China Minsheng Bank fifth, the four banks are between the best and the worst. At the same time, they also need to aim at the Industrial Bank, and then actively catch it up.

\section{B. The development of these six joint-stock commercial Banks is also uneven.}

According to the results of table III, the six joint-stock commercial banks are not balanced on 11 indicators.

1) In terms of profitability, Industrial Bank, Shanghai Pudong Development Bank's Return of equity and return on net worth is relatively high, while the China CITIC Bank's Return of equity and return on net worth is lowest. That is, the ability of Industrial Bank, Shanghai Pudong Development Bank to use capital profits and investment income is higher, the better the economic benefits of the enterprises has its own investment, and the less risk of the enterprises' investors will be with. And it is worthy of investment and continue to invest. However, the economic benefits and investment brought by China CITIC Bank's own investment are relatively low, which is not advantageous to other Banks.

2) In terms of solvency, liquidity ratio is an important part of commercial Banks in risk rating, which Banks have enough capital reserve important reference standard so as to guard against market risks, so it is also an important standard of bank solvency. Within the regulatory scope (liquidity ratio ratio $\geq 25 \%$ ), the higher ratios of China Merchants Bank and Industrial Bank indicate that the liquidity of the assets of the two banks is relatively good, and the efficiency of the use of assets is relatively high. However the Shanghai Pudong Development Bank and other banks are relatively lower. Therefore, in terms of liquidity of assets, Shanghai Pudong Development Bank needs to pay more attention to improve the liquidity of assets and the application efficiency of assets in a timely manner.

3) In terms of capital ability, In addition to China Merchants Bank's capital adequacy ratio, the other five are basically flat. In respect of the Turnover of current assets, the six Banks are far apart, the China Merchants Bank has far beyond the second Shanghai Pudong Development Bank. It shows that China Merchants Bank has a great advantage in terms of current assets turnover, and the other four banks is far behind. Integrated the two measures, China Merchants Bank capital ability obviously superior to other five banks, and Huaxia Bank is basic in the final position, so the Huaxia Bank should focus on strengthening their capital ability.

4) In the development trend of total asset growth rate, main business growth rate, and profit growth after tax, China Merchants, Industrial Bank and Shanghai Pudong Development Bank are basically superior to other banks, while Huaxia Bank's main business growth rate and China CITIC Bank's growth rate after tax is also at the lowest level. It indicates that the two banks urgently need to pay more attention to the growth of their main business and profits after tax, and pay more attention to adjusting their future development strategies.

5) In terms of non-performing loan ratio, six banks basically remain flat, and they are all relatively low. nonperforming loan ratio is one of the important indicators of evaluation of bank assets security. The lower the nonperforming loan ratio, the smaller the proportion of the total loans that the bank cannot recover, and the risk of capital recovery of the bank is relatively small, so the bank is relatively stable. [4]

\section{Conclusion}

\section{A. Elaboration from the model aspect.}

The article evaluates the comprehensive benefits of six joint-stock commercial banks in China. The grey correlation analysis method in the paper can be used not only for evaluation and comparison among different banks, but also for comparative analysis of different years in the same bank. And according to the highest score of each index and the correlation degree of each subject's score, we obtained the ranking of the overall quality of each subject. It further reveals the differences in the economic benefits of the six joint-stock commercial banks, and it also pointed out the main ways to improve economic efficiency. [3]

\section{B. Elaboration from the bank environment.}

In recent years, the bank's shareholding system reform and financial reform measures have made joint stock commercial banks obtained greater development. However there is still a great gap while the joint-stock commercial Banks compared with the traditional big four state-owned commercial Banks in our country, even compared with the foreign banks. So it is still hard to form a strong force in our country.

Therefore, in the future, if the banks want to be invincible in the fierce competition on the banking market, they should rely on the banking market, and even rely mainly on the profitability, debt repayment, and capital, development, and security capabilities to increase capital. At the same time, the banks should pay more attention to the bank's liquidity, safety, and soundness. As the rapid expansion of asset size, the joint- 
stock commercial banks must strive to raise their core capital level, enhance the capital adequacy and profitability, and then create their special features.[5] [6]

\section{ACKNOWLEDGMENT}

I would like to express my heartfelt gratitude to my tutor, Professor Rongping $\mathrm{Li}$, for her careful guidance and encouragement in the preparation of my dissertation. It is her tireless teaching that gave me infinite inspiration and guidance.

\section{REFERENCES}

[1] Xi Chen. A comprehensive evaluation study on the business strength of China's major joint-stock commercial Banks. [J]. Market modernization, 2016(20):73-74. (in Chinese)
[2] Rong ming Wang, Mingkai Zhang. Research on the competitiveness of listed Banks based on fuzzy comprehensive evaluation. . [J]. Value engineering, 2016(05). (in Chinese)

[3] Shenao Fang, Xiaohua Zheng. Evaluation of profitability of commercial Banks based on factor analysis. . [J]. Modern economic information, 2014(10):359-360. (in Chinese)

[4] Chenyang Xu. Performance evaluation of listed commercial Banks in China -- empirical research based on factor analysis. [J]. Business accounting, 2014(14):107-109. (in Chinese)

[5] James O’Brien, PawełJ. Szerszeń. An Evaluation of Bank Measures for Market Risk Before, During and After the Financial Crisis[J]. Journal of Banking and Finance, 2017.

[6] Tsai Sang-Bing, Chen Kuan-Yu, Zhao Hongrui, Wei Yu-Min, Wang Cheng-Kuang, Zheng Yuxiang, Chang Li-Chung, Wang Jiangtao. Using a Mixed Model to Explore Evaluation Criteria for Bank Supervision: A Banking Supervision Law Perspective. [J]. PloS one, 2016, 11(12).

[7] A. E. LaPlante, J. C. Paradi. Evaluation of bank branch growth potential using data envelopment analysis[J]. Omega, 2015, 52. 